cause, as he himself admits, its value is so far an unknown quantity. The profession has in the past properly refused, and should now and in the future refuse, to endorse any method which has not had the test of time, and in numerous hands. Prof. Koch has made wonderful and valuable contributions to scientific medicine, but in this new field of endeavor, the logical outgrowth of his pathological discoveries, we must not, simply on the basis of his success in pathological research, follow him blindly. When a case of tuberculosis treated by his method, after the lapse of one year, remains well, there will be time enough to prepare the laurel crown.

In the second place, there is an objection to extravagant praise of Dr. Koch in this connection, because, disguise it as we may, it still remains disagreeabiy patent that the failure to tell now what the medicament is and how it is made, when apparently sufficient data have been collected to warrant its use upon the human subject, and the acceptance of a fee therefor, smacks too much of quackery. In plain terms, it is vaunting, using and selling a secret nostrum.

So long as Prof. Koch confined himself to experimental use of his new remedy upon the lower animals, or to a limited and reasonable degree, upon the human subject, without fee, no one would dispute his moral and legal right to keep his knowledge to himself. But when once a fee has been accepted for the service, and a willingness expressed to serve others on the same terms, the experimental plea must be abandoned. And in the light of rumors of extortion, and charges by those always uncharitable to medical men, that nothing will be revealed until the few interested have made fortunes, further silence not only gives rise to further suspicion of Prof. Koch's professional honesty, but casts, by inference, discredit upon the medical profession at large.

Finally, there is an objection to extravagant praise of Prof. Koch in this connection, because, outside of the question of value and outside of the suggestion of quackery, this praise gives an undesirable boom to empiricism in medicine. Only a few days ago it was estimated that two thousand physicians had already come from foreign parts to Berlin to observe Prof. Koch's treatment, and by to-day's paper I see that in spite of the poor satisfaction experienced by those already there, the list of daily arrivals shows no decrease. Think of it! Thousands of physicians-Germans, Austrians, Italians, Russians, English and Americans (and possibly those of other nations), flocking to Berlin to see Prof. Koch's treatment, scrambling for places, and offering fabulous prices for a few drops of the liquid whose composition they do not know and cannot find out! And when asked why they want it, reply, "Because Koch thinks it will cure tuberculosis!" When has the practice of medicine witnessed such a spectacle? And THE JOUR-
NAL's praise of Koch's wisdom is helping to swell this crowd!

Hitherto the great fault of American physicians in the eyes of our European brethren has been this very thing-empiricism. In fact, we have been charged with having a monopoly of it. Now, of course, by this concourse of all nations in Berlin, we know that this charge is false, and I submit it to you-would it not be better, in view of all this, for THE JournaL, instead of encouraging, to caution its supporters? commending to their careful consideration the refusal of the French customs officer to allow the passage of the remedy sent to M. Pasteur, because the Government of his country (an excellent law) prohibited the admission of such things without a declaration of their composition.

By all means let us leave the further cultivation of empiricism to our German and English brethren, now that it has sprouted so vigorously among them. H. B. YounG, M.D.

Burlington, Ia., November 29, 1890.

\section{Euphorbia Pilulifera for Asthma.}

To the Editor:-Quite recently, at the suggestion of my friend Dr. E. T. Sabal, of Jacksonville, Florida, I have used the remedy above named, euphorbia pilulifera, for the relief of a most stubborn case of hereditary asthma, and the results are such that I feel warranted in calling the attention of the profession to it, and also making an effort to compile some statistics which will be of service to us in the future. It is a popular domestic remedy in Australia, where it is found as a common roadside weed, and has been used for the relief of coughs, colds and other like disturbances of the air-passages, but more especially in the treatment of asthma. Dr. Sabal advised me that he had used it in a number of very marked cases which had resisted the usual treatment in Florida, and he thought it might prove equally valuable in our northern climate. The only case in which I have employed it this far, is one which is developed apparently from an ordinary cold, and has proven most intractable during foggy weather, or when the relative humidity was great. Heretofore, under the treatment of other physicians, in this country and in England, and Australia, the attacks would last from one to three weeks, and even then he would require the liberal use of hypodermatics of morphine and atropine. In the course of twenty-four hours after the first symptoms appeared, the malady would be fully developed, and the patient, a young man, would be compelled to sit up until the disease had exhausted itself. With the exception of myself, all his previous attendants had used ipecac freely, and he had come to dread the attacks on account of the nausea produced by the treatment. By the cautious employment of 
atropine, morphine, and nitroglycerine, and the liberal use of oxygen gas, I had succeeded in lessening the severity and shortening the period to less than a week, but the results were much less satisfactory than when euphorbia was used, together with the above described combination subcutaneously. For hypodermatic use the following was employed:

R-Morphinæ sulphas. gr. I-4.

Atropinæe sulphas. gr. I- I 50 .

Trinitrin, gtt. I. m

Sig. For subcutaneous use; for one dose.

The formula adapted for the exhibition of euphorbia as follows:

R-Ext. euphorbæ pilulifera (P. D. \& Co's.). Glycerini, āā fl. oz. ij. m

Sig. Take one teaspoonful every three hours.

If those who have had experience with this remedy will kindly communicate the results of their observations to me, I will be glad to give them credit in the form of a collective report.

John Aul.De, M.D.

I 9 Io Arch street, Philadelphia, Dec. I 2, I890.

\section{A Correction.}

To the Editor:-In the issue of THF JOURNAL containing the report of the Mississippi Valley Medical Association meeting at Louisville, referring to my paper upon "Certainty in the Diagnosis of Tuberculosis" I am quoted as saying: "The disease is void of the slightest tendency to self-limitation." This I certainly did not say, nor did Dr. Porter, of St. Louis, in his interesting paper published in the same number of THE JOURNAL, take any such extreme grounds. $\mathrm{He}$ called in question Flint's doctrine of self-limitation, restricting the skepticism to cases which had advanced so far that the presence of disease could be established by physical signs. It was upon a series of such cases that Flint's teaching was based. Owing to pressure of time neither Dr. Porter's paper nor mine was discussed, but in conversation with him afterward he clearly ex. plained his position, and I think I am correct in stating it. Tuberculosis, advanced to the production of distinct subjective and objective signs is one thing; the incipient local disease, which, in many cases at least, can now be detected by skilful application of the bacteriological test, is clinically quite another. So far as experiments upon animals can throw light upon the question, there is good reason to believe in the self-limitation, and I would not like to go on record with such a sweeping statement as that quoted. I wrote as follows: "Tuberculosis is a disease which, once well under headway, is not in any marked degree, as compared with other infections, self-limited. Self-limitation is an uncertain staff upon which to lean. We can not deserve the name of workers, nor really win battles nor advance to higher fields, nor even pre- serve our self respect, by supineiy resting upon such support and awaiting a possible victory." Respectfully, Indianapolis, Ind. THEODORE POTTER, M.D.

\section{Shall The Journal be Removed to Washington?}

To the Editor:-Please place my vote on the list, as in favor of THE JOURNAI remaining at Chicago.

Austin, Tex., December 23, I890.

To the Editor:-About the removal of THE JOURNAL and building a house of our own; I think it advisable to do so, and would suggest Louisville, which is neither an Eastern, Western, Northern or Southern city, but truly a central one.

Smyrna, Tenn., December 23, 1890. J. W. Davis, M.D.

To the Editor:-The writer's subscription (as have those for every former one) for Vol. xv of ThE JOURNAL, will soon be forthcoming, and for the fact above he would regret a break in the file. To the ordinary observer the proposition to remove THe Journal to the Capital or elsewhere must have in its favor some occult reason or grounds, so palpable and strong are the objections. In all forms of journalism the argument for a central place of publication is vital, but in the special case of THE JOURNAL, it is tenfold stronger. The word "Association" gives the key to this statement. Surely reasons, at the present sufficient, and daily augmenting - not to mention success-would induce the common mind to think and say "ThE JournaI is exactly where it should be." Yours truly,

H. C. Markham, M.D.

Independence, Iowa, Dec. 27 , I 890.

\section{MISCELLANY.}

'Thi: Mattison Prizy. - With the object of advancing scientific study and settling a now mooted question, Dr. J. B. Mattison, of Brooklyn, offers a prize of $\$ 400$ for the best paper on "Opium Addiction as Related to Renal Disease," based upon these queries:

Will the habitual use of opium, in any form, produce organic renal disease?

If so, what lesion is most likely?

What is the rationale?

The contest is to be open for two years from Dec. I, I 890 , to either sex, and to any school or language. The prize paper is to belong to the American Association for the Cure of Inebriety, and to be published in a New York medical journal, Brooklyn Medical Journal, and Journal of Inebriety. Other papers presented are to be pub lished in some leading medical journal, as their authors may select. All papers are to be in possession of the Chairman of Award Committee, on, or before January I, I 893 . 